\title{
MOLECULAR DETERMINANTS OF PATHOGENICITY AND HOST SPECIFICITY OF HIGHLY PATHOGENIC H5N1 BiH ISOLATES
}

\author{
Teufik Goletić ${ }^{1}$, Aida Kustura ${ }^{1}$, Abdulah Gagić1, Vladimir Savić ${ }^{2}$ Emina Rešidbegović ${ }^{1}$, Aida Kavazović1, \\ Edin Šatrović ${ }^{1}$, Timm Harder ${ }^{3}$, Senad Prašović ${ }^{1}$, Hajrudin Beširović ${ }^{1}$, Amer Alić ${ }^{1}$
}

(C) 2019 by Acta Medica Saliniana ISSN 0350-364X

DOI: $10.5457 / 519$

Teufik Goletić Aida Kustura Abdulah Gagić Vladimir Savić Emina Rešidbegović Aida Kavazović Edin Šatrović Timm Harder Senad Prašović Hajrudin Beširović Amer Alić

\section{Afiliations:}

${ }^{1}$ University of Sarajevo - Veterinary faculty, National Reference Laboratory for Avian Influenza and Newcastle Disease, 71000 Sarajevo, Bosnia and Herzegovina,

${ }^{2}$ Croatian Veterinary Institute, Poultry Centre, 10000 Zagreb, Croatia,

${ }^{3}$ Friedrich-Loeffler-Institut, Federal Research Institute for Animal Health, 17493 Greifswald-Insel Riems, Germany

Corresponding author:

Teufik Goletić

E mail: teufik.goletic@vfs.unsa.ba

\section{ABSTRACT}

Background: Towards preparation for a possible influenza pandemic, investigation of the molecular characteristics of the circulating avian $\mathrm{H}_{5} \mathrm{~N}_{1}$ influenza virus strains is of crucial importance. These $\mathrm{H}_{5} \mathrm{~N}_{1}$ viruses continue to spread, to infect animals and humans and to evolve and diversify providing so an ever-looming pandemic threat.

Aim: To identify genetic structure and molecular biological characteristics of BiH's isolates of $\mathrm{H}_{5} \mathrm{~N}_{1}$ HPAI as well as to assess the level of pathogenicity, phylogenetic origin and host- specificity of the isolates.

Material and Methods: SPF embryonated chicken eggs were used for virus isolation. Viral RNA extracted using QIAamp viral RNA kit and manufacturer's protocol (QIAGEN ${ }^{\circledR}$ ) was used for PCR amplification. cDNA synthesis and PCR amplification of the coding region, using gene specific primer sets (primer sequences available on request), were carried out for all eight viral RNA segments separately. The Prism Big Dye Terminator v1.1 cycle sequencing kit (Applied Biosystems) was used and products were analyzed on an automatic ABI PRISM 3130 genetic analyzer (Applied Biosystems). Nucleotide sequences were analyzed using Bioedit software (v. 7.o.9.o) with an engine based on the ClustalW 1.4 algorithm. MEGA software (v. 4,0), using the neighbor joining tree inference analysis with the Tamura-Nei $\gamma$-model, was used to estimate phylogenies and calculate bootstrap values from the nucleotide sequences.

Results: Full-length nucleotide sequences of the A/Cygnus olor/BIH/1/2006 $\left(\mathrm{H}_{5} \mathrm{~N}_{1}\right)$ strain were deposited in EMBL Nucleotide Sequence Database under accession nos. FN1860o8 to FN186014 and FM20943. The pathogenicity and host specificity of this strain, as polygenic traits, are determined in silico by the structure of its proteins, especially surface glycoproteins, HA and NA. Multibasic amino acid stretch PQGERRRKKR/GLF, marker of strains highly pathogenic to poultry, was present at the HA cleavage site of $\mathrm{BiH}$ strain. The RBS was typical for avian influenza viruses and contained Gln and Gly at positions 238 and 240 ( $\mathrm{H}_{5}$ numbering) that is,226 and 228 according to $\mathrm{H}_{3}$ numbering with seven potential glycosylated sites but with increased binding to alphaz-6 sialoglycans thanks to substitutions, as follows, $110 \mathrm{~N}, 171 \mathrm{~N},{ }_{171} \mathrm{~N}$, $172 \mathrm{~A}, 205 \mathrm{R}$ and $251 \mathrm{P}$. NA structure assigned this strain to the $\mathrm{Z}$ genotype, characterized also by the deletion of the five amino acid residues of the NS1 protein (positions 8o-84). Amino acid residues, typical for the avian influenza viruses, were revealed in 40 out of 43 positions of $\mathrm{M}_{1}, \mathrm{M} 2, \mathrm{NP}, \mathrm{PA}, \mathrm{PB} 2$ and $\mathrm{HA}$, determining the host range specificity. Phylogenetic analysis of the HA gene revealed that $\mathrm{BiH}$ isolates belonged to genetic clade 2.2., and presence of aspartic acid at the position of 403 of $\mathrm{HA}$ locate $\mathrm{BiH}$ isolates in 2.2.2. sub-clade.

Conclusions: The BiH's isolates were determined as HPAI virus with genes sequences closely related to A/Cygnus olor/Astrakhan/Asto5-2-10/2005 $\left(\mathrm{H}_{5} \mathrm{Nl}_{1}\right)$. Three residues $(\mathrm{M} 2-28 \mathrm{~V}$ and $78 \mathrm{~K}, \mathrm{NP}-33 \mathrm{I})$, typical of human influenza viruses, were found, indicating a certain degree of intercurrent evolutionary adaptive changes in $\mathrm{BiH}$ isolates. Sequence comparison of HA and NA segments with relevant sequences in GenBank revealed that the $\mathrm{BiH}$ isolates and the ones from the southern Russia (Astrakhan region) group together phylogenetically, forming a monophyleticcluster in both genes indicating that these isolates have evolved from the same origin. Sequence derived phenotype markers of NA protein (E99, V129, D131, R136, H255 and Y256) as well as of M2 protein (26L, ${ }_{27} \mathrm{~V}, 30 \mathrm{~A}, \mathrm{~S}_{31}$ and $\mathrm{G}_{34}$ ) showed that the isolates have an oseltamivir and amantadine sensitive genotype.

Key words: $\mathrm{H}_{5} \mathrm{~N}_{1}$, HPAI, pathogenicity, phylogeny, host-specificity. 


\section{INTRODUCTION}

Avian influenza is a viral infection of domestic and wild avian species with a complex ecology involving reassortment of viral gene segments and transmission among different avian and mammalian species carrying the risk of the emergence of pandemic influenza. Influenza A virus contains eight negativestranded RNA genomic segments. The three largest RNA segments encode the three viral RNA-dependent RNA polymerase proteins: polymerase acidic protein (PA), polymerase basic protein $1(\mathrm{~PB} 1)$ and $\mathrm{PB} 2$. The RNA segment for $\mathrm{PB} 1$ also encodes a small 87-residue nonstructural protein, $\mathrm{PB} 1-\mathrm{F}_{2}$, with apoptotic functions. The three intermediate- size RNA segments encode hemagglutinin (HA), neuraminidase (NA) and the nucleoprotein (NP). The larger of the remaining two segments encodes the M1 matrix protein and the $\mathrm{M}_{2}$ ion- channel protein, and the smaller one encodes two nonstructural proteins, NS1A and NS2/NEP. According to disease severity avian influenza is classified either as low pathogenic avian influenza (LPAI) or as highly pathogenic avian influenza (HPAI), later resulting in nearly $100 \%$ mortality in infected domestic flocks. From the plethora of different avian influenza viruses (AIV), only some strains of $\mathrm{H}_{5}$ and $\mathrm{H}_{7}$ subtypes have become highly pathogenic so far. The HPAI $\mathrm{H}_{5} \mathrm{~N}_{1}$ virus first appeared in 1996 in geese in Guangdong, China, and continues to circulate in the poultry population in many countries, mainly in Asia and North Africa, particularly in recent years in Egypt. These $\mathrm{H}_{5} \mathrm{~N}_{1}$ viruses continue to spread, to infect animals and humans and to evolve and diversify thus contributing to the emergence of different virus clades, providing an ever-looming pandemic threat. Although the HPAI $\mathrm{H}_{5} \mathrm{~N}_{1}$ viruses so far have not demonstrated the ability to transmit efficiently between humans, they remain a public health concern because of the high case-fatality rates associated with $\mathrm{H}_{5} \mathrm{~N}_{1}$ infection. The conditions necessary for cross infection are essentially provided by agricultural practices that bring together humans, poultry and other susceptible species. It is important to underline that the recent studies on ferrets showed that only limited changes are required for the $\mathrm{H}_{5} \mathrm{~N}_{1}$ virus to acquire the ability for airborne transmission [1-3] .

The first case of HPAI $\mathrm{H}_{5} \mathrm{~N}_{1}$ in wild birds in Bosnia and Herzegovina (BiH) was identified in February 2006 [3], after the virus had been discovered in many parts of Europe in 2005/2006. One of the stages of preparation towards a possible pandemic is a thorough investigation of the molecular characteristics of the circulating HPAI, including $\mathrm{H}_{5} \mathrm{~N}_{1}$ strains. Therefore, the aim of this study was to identify genetic structure and molecular biological characteristics of BiH's isolates of $\mathrm{H}_{5} \mathrm{~N}_{1} \mathrm{HPAI}$ as well as to assess their pathogenicity, phylogenetic origin and host- specificity, especially having in mind possible molecular changes associated with the transmission of these isolates to humans.

\section{SUBJECT AND METHODS}

Virus isolation. Pooled organ suspensions (lungs, brain, liver, duodenum and pancreas) and oropharyngeal and cloacal swabs from two dead Mute swans (Cygnus olor), originating from the Pliva Lake located flock, which was highly suspect of HPAI infection, were processed separately according to the World Organization for Animal Health (OIE) recommendations [4]. Specific- pathogen-free (SPF) embryonated chicken eggs (VALO, Lohmann Tierzucht, Cuxhaven, Germany SPF eggs) were used for virus isolation in accordance with the procedure described elsewhere [4-5]. All samples were processed at the enhanced bio-safety level (BSL) two in the National Reference Laboratory for Avian Influenza and Newcastle Disease at the Sarajevo Veterinary Faculty.

RNA isolation, RT-PCR and sequencing. Molecular characterization of the Bosnia and Herzegovina outbreak $\mathrm{H}_{5} \mathrm{~N}_{1}$ virus was performed by sequencing of all eight viral genes at the Friedrich-LoefflerInstitut (Greifswald - Insel Riems, Germany). RNA isolation was done manually from the allantoic fluids of the virus isolates using the QIAamp viral RNA kit (Qiagen) as described in the manufacturer's protocol. Synthesis of cDNA, performed by using the Uni12 primer set that is complementary to the 12 conserved nucleotides at the 3'-end of the viral RNA and subsequent PCR amplification, in which CDNA fragments where amplified by segment- specific primers, where performed as described elsewhere [6]. Each PCR reaction was separately carried out twice, and two independently generated PCR products were sequenced in both directions. The Prism Big Dye Terminator v1.1 cycle sequencing kit (Applied Biosystems) was used and products were analyzed on an automatic ABI PRISM 3130 genetic analyzer (Applied Biosystems).

Phylogenetic analyses. After the sequencing, assembling of achieved sequences and removing of the low quality sequence data, nucleotide sequence translation into the protein sequence, the additional multiple sequence alignments and processing were performed with the Bioedit software version 7.0.9.o [7] with an engine based on the ClustalW 1.4 algorithm. Blast homology searches (http://www.ncbi.nlm. nih.gov/blast) were used to retrieve the top fifty homologous sequences for the sequenced genes from the GenBank database. Phylogenetic and molecular evolutionary analyses based on the respective genes' alignments were conducted with the Molecular Evolutionary Genetics Analysis (MEGA, version 4.0) software [8] using the neighbor joining tree inference analysis with the Tamura-Nei $\gamma$-model, with 2000 bootstrap replications. The topology of the constructed trees was confirmed by using minimum evolution with maximum composite likelihood model and also by maximum parsimony as implemented in MEGA 4.o. Potential N-linked glycosylation sites were predicted with the NetNGlyc 1.o Server [9]. A threshold value 
of an average potential score $>0.5$ was set to predict glycosylated sites. Lineage determination of studied genes was established by Influenza A Virus Genotype Tool [10].

\section{RESULTS AND DISCUSSION}

First ever recorded outbreak of highly pathogenic $\mathrm{H}_{5} \mathrm{~N}_{1}$ in $\mathrm{BiH}$ arises in February 2006 among flock of Mute swan [3]. The entire genome sequencing showed that all $\mathrm{BiH}$ isolates were $100 \%$ identical. After this, the virus strain was designated A/Cygnus olor/BIH/1/2006 $\left(\mathrm{H}_{5} \mathrm{~N}_{1}\right)$. According to the Influenza A Virus Genotype Tool [10] the studied genes of the investigated $\mathrm{BIH}$ isolates belong to the following lineages: $\mathrm{PB}_{2}(\mathrm{~K}), \mathrm{PB}_{1}$ (G), PA (D), HA (5J), NP (F), NA (1J), MP (F), NS (1E). To determine molecular characteristics and pathotypes of isolates, complete sequences of the coding regions of all eight segments of $\mathrm{A} /$ Cygnus olor/BIH/1/2006 $\left(\mathrm{H}_{5} \mathrm{~N}_{1}\right)$ genes were sequenced and then analyzed (Table 1 and 2). The positions of the nucleotide (nt) and the amino acid (aa) in the respective sequences, unless otherwise emphasized, are numbered using the $\mathrm{H}_{5} \mathrm{~N}_{1}$ numbering system which includes the amino acid methionine at the position one, but also all the gaps formed by the evolutionary changes in the genome of the virus. Pathotypes of the study isolates were established by determining the multibasic amino acid stretch PQGERRRKKR/GLF at the cleavage site of the precursor hemagglutinin molecule (positions 337-349 of HAo molecule). The importance of this finding is that aforementioned amino acid stretch is marker of strains highly pathogenic to poultry [11-12], categorizing $\mathrm{BiH}$ isolates as HPAI

Table 1. Genome sequencing results of A/Cygnus olor/BIH/1/2006 ( $\left.\mathrm{H}_{5} \mathrm{~N}_{1}\right)$

\begin{tabular}{|c|c|c|c|c|c|}
\hline $\begin{array}{l}\text { Genome } \\
\text { segment }\end{array}$ & $\begin{array}{l}\text { Nucleotides } \\
\text { (nt) number }\end{array}$ & $\begin{array}{l}\text { Length of coding } \\
\text { sequence }\end{array}$ & Coded protein & nt sequence & $\begin{array}{l}\text { Length of aa } \\
\text { sequence }\end{array}$ \\
\hline $\mathrm{PB}_{2}$ & 2291 & 2280 & $\mathrm{~PB} 2$ protein & $12-2291$ & 759 \\
\hline \multirow{2}{*}{$\mathrm{PB} 1$} & \multirow{2}{*}{2285} & \multirow{2}{*}{2274} & $\mathrm{~PB} 1$ protein & $1-2274$ & 757 \\
\hline & & & $\mathrm{PB}_{1}-\mathrm{F}_{2}$ & $95-367$ & 90 \\
\hline $\mathrm{PA}$ & 2197 & 2148 & PA protein & $9-2157$ & 716 \\
\hline HA & 1707 & 1707 & hemagglutinin & $1-1707$ & 568 \\
\hline NP & 1519 & 1497 & Nucleoprotein & $22-1518$ & 498 \\
\hline NA & 1398 & 1350 & Neuraminidase & $36-1385$ & 449 \\
\hline \multirow[b]{2}{*}{ M } & \multirow[b]{2}{*}{969} & \multirow[b]{2}{*}{960} & Mi protein & $1-759$ & 252 \\
\hline & & & M2 protein & $\begin{array}{l}1-26 \Phi 715- \\
960\end{array}$ & 90 \\
\hline \multirow[b]{2}{*}{ NS } & \multirow[b]{2}{*}{851} & \multirow[b]{2}{*}{$1-823$} & NS1 protein & $1-678$ & 225 \\
\hline & & & NEP $\left(\mathrm{NS}_{2}\right)$ protein & $\begin{array}{l}1-29 \Phi 488 \\
-823\end{array}$ & 121 \\
\hline
\end{tabular}

Table 2 - Comparison of the amino acid and nucleotide sequences studied with one of the most phylogenetically related isolates: ${ }^{1}$ Results of the sequencing and access number (code) are stored in the EMBL gene data bank; 2 Asynonymous changes are accentuated by italics; 3 The amino acid and nucleotide substitutions are shown using the corresponding amino acid sequences A/Cygnus olor/Astrakhan/Asto5-2-7/2005 ( $\left.\mathrm{H}_{5} \mathrm{~N}_{1}\right) ; 4$ Percentage of identity of the phylogenetic most closely related isolates A/Cygnus olor/BIH/1/2006 and A/ Cygnus olor/Astrakhan/Asto5-2- 7/2005 ( $\left.{ }_{5} \mathrm{~N}_{1}\right)$; SNP - single nucleotide polymorphism.

Table 2. Comparison of the amino acid and nucleotide sequences studied with one of the most phylogenetically related isolates

\begin{tabular}{|c|c|c|c|c|c|c|}
\hline \multirow{2}{*}{ Segment } & \multicolumn{3}{|c|}{$\begin{array}{l}\text { A/Cygnus olor/BIH/1/2006 } \\
\left(\mathrm{H}_{5} \mathrm{Ni}_{1}\right)\end{array}$} & \multicolumn{3}{|c|}{$\begin{array}{l}\text { A/Cygnus olor/Astrakhan/Asto5-2- } \\
7 / 2005\left(\mathrm{H}_{5} \mathrm{N1}\right)\end{array}$} \\
\hline & Code $^{1}$ & $\begin{array}{l}\text { length } \\
\text { (nt) }\end{array}$ & $\begin{array}{l}\text { length } \\
\text { (aa) }\end{array}$ & Code $^{1}$ & nt subst. ${ }^{\text {(snp), } 2}$ & aa subst. ${ }^{3}$ \\
\hline $\mathrm{PB} 2$ & $\mathrm{FN}_{186014}$ & 2291 & 759 & DQ363921 & $\begin{array}{l}\mathrm{T}_{708 G} \\
\mathrm{C}_{1275 \mathrm{~T}} \\
A_{1} 870 G\end{array}$ & $\begin{array}{l}\mathrm{S} 263 \mathrm{~A} \\
\mathrm{~K} 627 \mathrm{E}\end{array}$ \\
\hline$\overline{P B 1}$ & FN186013 & 2285 & 757 & $\mathrm{DQ}_{363920}$ & $\begin{array}{l}\text { G504A; } \\
\text { C1083T; } \\
\text { A1200G; } \\
\text { G1751A; } \\
C_{1803 T}\end{array}$ & $\mathrm{R} 584 \mathrm{H}$ \\
\hline
\end{tabular}




\begin{tabular}{|c|c|c|c|c|c|c|c|}
\hline PA & FN186012 & 2197 & 716 & $\mathrm{DQ}_{3} 63922$ & $\begin{array}{l}\mathrm{C}_{370 \mathrm{~A}} ; \\
\mathrm{T} 1665 \mathrm{C} ; \\
\mathrm{C}_{1687 \mathrm{~T}} ; \\
\mathrm{A}_{1808 G} ; \\
\mathrm{T} 2185 \mathrm{C} ; \\
\mathrm{C}_{2187 \mathrm{~A}}\end{array}$ & $\mathrm{~K} 60_{3} \mathrm{R}$ & 99 \\
\hline HA & FM209433 & 1707 & 568 & $\mathrm{DQ}_{3} 63923$ & $\begin{array}{l}\text { G153A; } \\
\text { C252T; } \\
\text { C87oT; } \\
\text { T985C; } \\
\text { A1191G; } \\
\text { T1684G }\end{array}$ & $\begin{array}{l}\mathrm{F}_{329 \mathrm{~L}} \\
\mathrm{~L}_{562 \mathrm{~V}}\end{array}$ & 99 \\
\hline NP & FN186oo9 & 1519 & 498 & $\mathrm{DQ}_{3} 63930$ & none & none & 100 \\
\hline NA & FN186oo8 & 1398 & 449 & $\mathrm{DQ}_{363924}$ & $\begin{array}{l}\text { G149T; } \\
\text { G321A; } \\
\text { T339C; } \\
\text { A1024G }\end{array}$ & $\begin{array}{l}\mathrm{S}_{50 I} \\
\mathrm{~T}_{342 \mathrm{~A}}\end{array}$ & 99 \\
\hline M & FN186010 & 969 & $\begin{array}{l}252 \\
\left(\mathrm{M}_{1}\right)\end{array}$ & $\mathrm{DQ}_{3} 63928$ & $\begin{array}{l}A_{43} G ; G_{52} A ; \\
\mathrm{T}_{72} \mathrm{C} ;\end{array}$ & $\begin{array}{l}\mathrm{I} 15 \mathrm{~V} \\
\mathrm{G} 18 \mathrm{~S}\end{array}$ & 99 \\
\hline NS & FN186011 & 851 & $\begin{array}{l}225 \\
(\mathrm{NS} 1)\end{array}$ & $\mathrm{DQ}_{363927}$ & $\begin{array}{l}T_{41} A ; \\
\mathrm{C}_{162} \mathrm{~T}\end{array}$ & $\mathrm{~F}_{14} \mathrm{Y}$ & 99 \\
\hline
\end{tabular}

The positions and number of glycosylation sites in HA are important for the virus pathogenicity, immune evasion, spillover and adaptation among influenza reservoir [13], and the appearance of new glycosylation sites can significantly change the antigenic and molecular biological characteristics of a virus. The study of $\mathrm{BiH}$ strain showed seven potential glycosylated sites in its HA (positions 27, 39, 181, 302, 500, 559) and three in NA (positions 88, 146 and 235 as per $\mathrm{H}_{5} \mathrm{~N}_{1}$ numbering system) and did not reveal any new glycosylation sites. The ability of the virus to replicate in different host species is further strongly influenced by the type of sialic acid and the binding type in the host (alphaz-3 or alphaz-6), as well as the amino acid receptor binding site (RBS) at positions 226 and 228 of viral subunit $\mathrm{HA}_{1}$ [14-16]. RBS of $\mathrm{BiH}$ strain was typical for avian influenza viruses and contained Gln and Gly at positions 238 and 240 ( $\mathrm{H}_{5}$ numbering) that is, 226 and 228 according to $\mathrm{H}_{3}$ numbering. However, other amino acid residues of HA molecule, found in $\mathrm{BiH}$ strain $(110 \mathrm{~N}, 171 \mathrm{~N}, 171 \mathrm{~N}, 172 \mathrm{~A}, 205 \mathrm{R}$ and $251 \mathrm{P})[17]$, can increase binding to human alphaz-6 sialoglycans receptors, otherwise preferred by human influenza $\mathrm{A}$ viruses (human IAV).

It is thought that amino acid residues located at certain positions of HA play an important role in the pathogenicity of influenza viruses. The reverse genetic approach $[18,19]$ has shown that substitutions of single amino acid residues at positions 113, 124, 142, 154, 228 and 233 of HA of highly pathogenic viruses with the residues typical for moderately pathogenic viruses reduces the virus pathogenicity, and vice versa. Analysis of the deduced HA amino acid sequences of the $\mathrm{BiH}$ isolates showed that the amino acid residues located at these positions, except the residue at the position 154, are occupied by the residues typical for highly pathogenic viruses (Table 3).

Table 3. Amino acid residues important for influenza virus pathogenicity

\begin{tabular}{llll}
\hline $\begin{array}{l}\text { Amino acid } \\
\text { position }\end{array}$ & $\begin{array}{l}\text { A/goose/Hong Kong/437-10/1999 } \\
\left(\mathrm{H}_{5} \mathrm{~N}_{1}\right) \text { (moderately pathogenic) }\end{array}$ & $\begin{array}{l}\text { A/chicken/HongKong/ } \\
\text { YU562/2001 (H5N1) (HPAIV) }\end{array}$ & $\begin{array}{l}\text { A/Cygnus olor/BIH/1/2006 } \\
\left(\mathrm{H}_{5} \mathrm{~N}_{1}\right)\end{array}$ \\
\hline 113 & $\mathrm{~N}$ & $\mathrm{D}$ & $\mathrm{D}$ \\
124 & $\mathrm{~T}$ & $\mathrm{I}$ & $\mathrm{I}$ \\
142 & $\mathrm{D}$ & $\mathrm{E}$ & $\mathrm{E}$ \\
154 & $\mathrm{H}$ & $\mathrm{L}$ & $\mathrm{Q}$ \\
228 & $\mathrm{E}$ & $\mathrm{K}$ & $\mathrm{K}$ \\
233 & $\mathrm{P}$ & $\mathrm{S}$ & $\mathrm{S}$ \\
\hline
\end{tabular}

HPAI $\mathrm{H}_{5} \mathrm{~N}_{1}$ can infect humans even though their HAs, like HAs of other avian influenza viruses, interact preferentially with alphaz-3 cell receptors [15]. Therefore, the bird-to-human transmission of a virus is determined by the changes, not only in the RBS, but also in the structure of internal and nonstructural proteins (Table 4). Amino acid residues, typical for the avian influenza viruses, were revealed in 40 out of 43 
positions of $\mathrm{M} 1, \mathrm{M} 2, \mathrm{NP}, \mathrm{PA}, \mathrm{PB} 2$ and $\mathrm{HA}$, determining the host range specificity. Three residues (M2 - 28V and $78 \mathrm{~K}, \mathrm{NP}-33 \mathrm{I})$, typical of human influenza viruses, were found, indicating a certain degree of intercurrent evolutionary adaptive changes in $\mathrm{BiH}$ isolates.

Table 4. Amino acid residues important for host specificity of influenza viruses

\begin{tabular}{|c|c|c|c|c|}
\hline Protein & $\begin{array}{l}\text { Amino acid } \\
\text { position }\end{array}$ & AIV & Human IAV & A/Cygnus olor/BIH/1/2006 $\left(\mathrm{H}_{5} \mathrm{Nl}\right)$ \\
\hline \multirow[t]{7}{*}{$\overline{\mathrm{HA}}$} & 148 & S & $\mathrm{T}$ & S \\
\hline & 202 & E & $\mathrm{D}$ & E \\
\hline & 205 & K & S & $\mathrm{R}$ \\
\hline & 206 & $\mathrm{~L}$ & I & $\mathrm{L}$ \\
\hline & 238 & $\mathrm{Q}$ & $\mathrm{L}$ & $\mathrm{Q}$ \\
\hline & 239 & S & A & S \\
\hline & 240 & G & S & G \\
\hline$\overline{\mathrm{M}}$ & 137 & $\overline{\mathrm{T}}$ & $\bar{A}$ & $\mathrm{~T}$ \\
\hline \multirow[t]{5}{*}{$\overline{\mathrm{M} 2}$} & 16 & $\bar{E}$ & $\mathrm{G}$ & $\bar{E}$ \\
\hline & 20 & $\mathrm{~S} / \mathrm{N}$ & $\mathrm{N}$ & S \\
\hline & 28 & I & $\mathrm{I} / \mathrm{V}$ & $\mathrm{V}$ \\
\hline & 55 & $\mathrm{~L}$ & $\mathrm{~F}$ & $\mathrm{~L}$ \\
\hline & 78 & $\mathrm{Q}$ & K & $\mathrm{K}$ \\
\hline \multirow[t]{11}{*}{$\overline{\mathrm{NP}}$} & 31 & $\overline{\mathrm{R}}$ & $\bar{K}$ & $\overline{\mathrm{R}}$ \\
\hline & 33 & V & I & I \\
\hline & 61 & I & $\mathrm{L}$ & I \\
\hline & 100 & $\mathrm{R}$ & V & $\mathrm{R}$ \\
\hline & 127 & E & $\mathrm{D}$ & E \\
\hline & 136 & $\mathrm{~L}$ & M & $\mathrm{L}$ \\
\hline & 214 & $\mathrm{R}$ & K & $\mathrm{R}$ \\
\hline & 283 & $\mathrm{~L}$ & $\mathrm{P}$ & $\mathrm{L}$ \\
\hline & 293 & $\mathrm{R}$ & K & $\mathrm{R}$ \\
\hline & 313 & F & Y & F \\
\hline & 375 & D & $\mathrm{G} / \mathrm{E}$ & $\mathrm{D}$ \\
\hline \multirow[t]{10}{*}{$\overline{\mathrm{PA}}$} & 28 & $\mathrm{P}$ & $\mathrm{L}$ & $\bar{P}$ \\
\hline & 55 & $\mathrm{D}$ & $\mathrm{N}$ & $\mathrm{D}$ \\
\hline & 65 & S & $\mathrm{L}$ & S \\
\hline & 100 & V & A & $\mathrm{V}$ \\
\hline & 241 & C & Y & $C$ \\
\hline & 312 & K & $\mathrm{R}$ & $\mathrm{K}$ \\
\hline & 382 & E & $\mathrm{D}$ & E \\
\hline & 400 & $\mathrm{Q} / \mathrm{T} / \mathrm{S}$ & $\mathrm{L}$ & S \\
\hline & 409 & S & $\mathrm{N}$ & S \\
\hline & $55^{2}$ & $\mathrm{~T}$ & S & $\mathrm{T}$ \\
\hline \multirow[t]{8}{*}{$\overline{\mathrm{PB} 2}$} & 44 & $\mathrm{~A}$ & S & $\mathrm{A}$ \\
\hline & 81 & $\mathrm{~T}$ & M & $\mathrm{T}$ \\
\hline & 199 & A & S & A \\
\hline & 271 & $\mathrm{~T}$ & A & $\mathrm{T}$ \\
\hline & 588 & A & I & A \\
\hline & 613 & V & $\mathrm{T}$ & $\mathrm{V}$ \\
\hline & 661 & A & $\mathrm{T}$ & A \\
\hline & 674 & $\mathrm{~A} / \mathrm{S}$ & $\mathrm{T}$ & A \\
\hline
\end{tabular}

Further analysis of the viral genomes NA structures assigned $\mathrm{BiH}$ isolates to the $\mathrm{Z}$ genotype of influenza viruses, which is characterized by the deletion of 20 residues (positions 49-68) from the NA stalk. This deletion has been observed in many HPAIV $\mathrm{H}_{5} \mathrm{~N}_{1}$ isolates and is suggested to be adaptation for efficient replication in chickens. Numbering of amino acid positions does not include the above-mentioned 
deletions. $\mathrm{Z}$ genotype is also characterized by the deletion of the five amino acid residues of the $\mathrm{NS}_{1}$ protein (positions $80-84$ ) found in $\mathrm{BiH}$ isolates. It should be noted that the nonstructural NS1 protein from $\mathrm{BiH}$ strain has Glu (E) at position 92, located near the RNA-binding domain of this protein, determining the interferon resistance of a virus, probably due to suppression of antiviral cell defense by small interfering RNAs [20], as well as increased virulence towards pigs [21].

Particular attention was paid to the molecular characterization of $\mathrm{BiH}$ HPAI $\mathrm{H}_{5} \mathrm{~N}_{1}$ isolates in order to determine amino acid residues essential for virus resistance to inhibitors of NA and $\mathrm{M}_{2}$ ion channel. The major molecular markers of resistance to antiviral oseltamivir (NA inhibitor) are located at 99, 129, 131, 136, 255, and 256 [22]. Analysis of the amino acid residues E99, V129, D131, R136, H255 and Y256 of $\mathrm{BiH}$ strain shows that it belongs to oseltamivir sensitive genotype. Furthermore, by analyzing the M2 protein of $\mathrm{BiH}$ isolates, the identified amino acid residues linked to virus-mediated resistance to $\mathrm{M} 2$ ion channel inhibitors have been determined. Thus, at positions 26 , $27,30,31$ and 34 , which are responsible for interaction with the amantadine antiviral drug [23], amino acid residues L, V, A, S and G were established, respectively. On the basis of these findings it can be asserted that studied $\mathrm{BiH}$ strain is fully sensitive to the amantadine. To determine the origin of the A/Cygnus olor/ $\mathrm{BIH} / 1 / 2006\left(\mathrm{H}_{5} \mathrm{~N}_{1}\right)$ strain, phylogenetic analysis of all genomic fragments was carried out. The genes of all proteins, including internal and nonstructural ones (data not shown), were determined to be closely related to the genes of other AIV $\mathrm{H}_{5} \mathrm{~N}_{1}$ subtype. The phylogenetic trees of HA and NA are shown in Figs. 1 and 2, respectively, revealing that $\mathrm{BiH}$ isolates belong to genetic clade 2.2. (closely related to the Qinghailike viruses), while the presence of aspartic acid at the position of 403 of HA locates $\mathrm{BiH}$ isolates in 2.2.2. subclade.

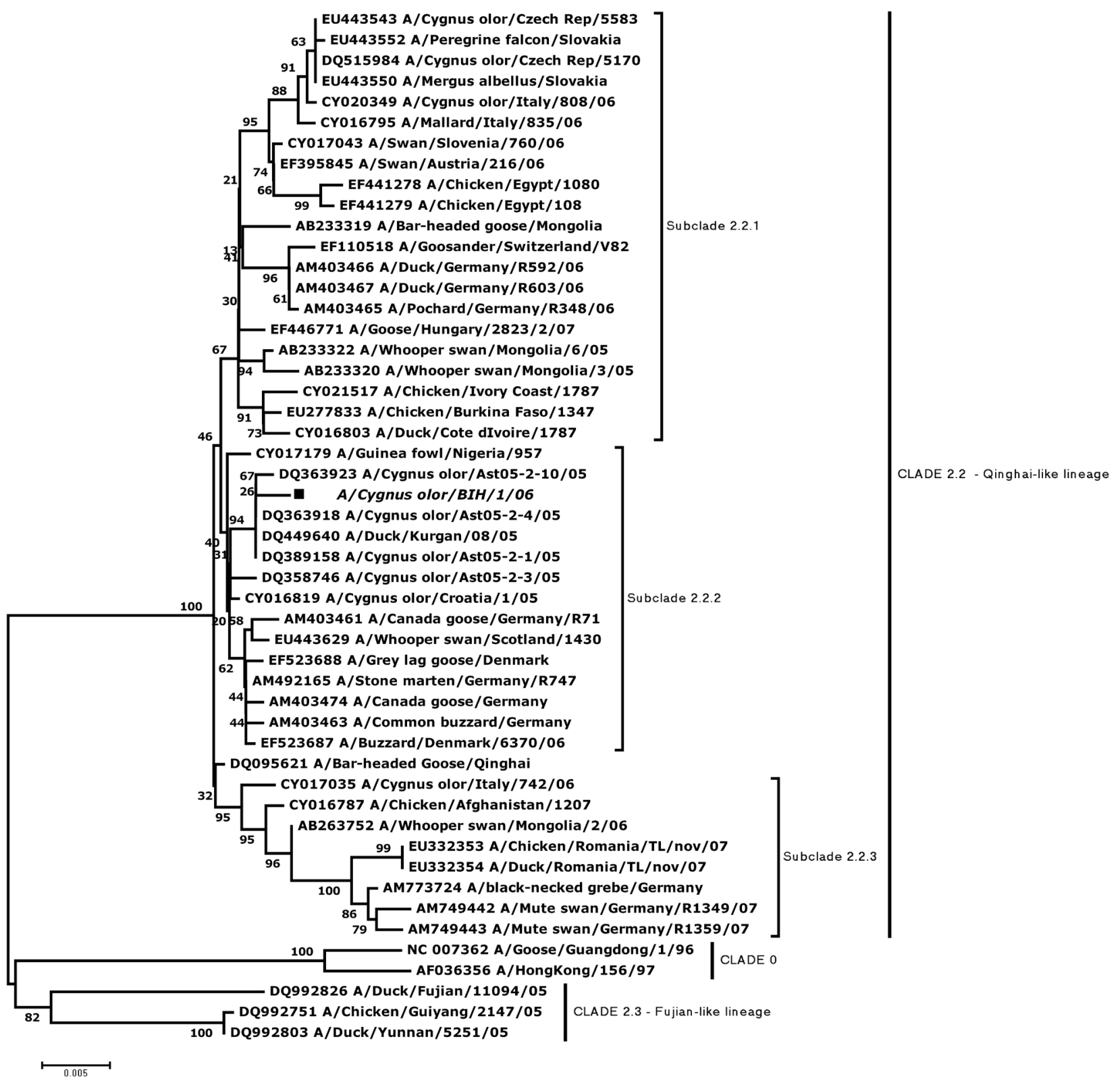

Figure 1. Evolutionary relationship of the HA gene of BIH HPAIV $\mathrm{H}_{5} \mathrm{~N}_{1}$ 
Figure 1 shows the evolutionary relationship of the HA gene of BIH HPAIV $\mathrm{H}_{5} \mathrm{~N}_{1}$ compared to the fifty most homologous sequences obtained from GenBank. The tree comprising nucleotide sequences of the whole coding region (nt 1-1707) was generated by the neighbor joining method using the Tamura-Nei $\gamma$-model as implemented in MEGA 4.o. Bootstrap values after 2000 resamplings in percent are indicated at key nodes. The lengths of the horizontal lines are proportional to the number of nucleotide differences per site. Scale bar indicates number of nucleotide substitutions per site. Genetic clades are designated according to $\mathrm{WHO} /$ FAO/OIE $\mathrm{H}_{5} \mathrm{~N}_{1}$ Evolution Working Group [24]. Tree is midpoint-rooted for means of clarity. The BIH virus is highlighted by italic bold letters.

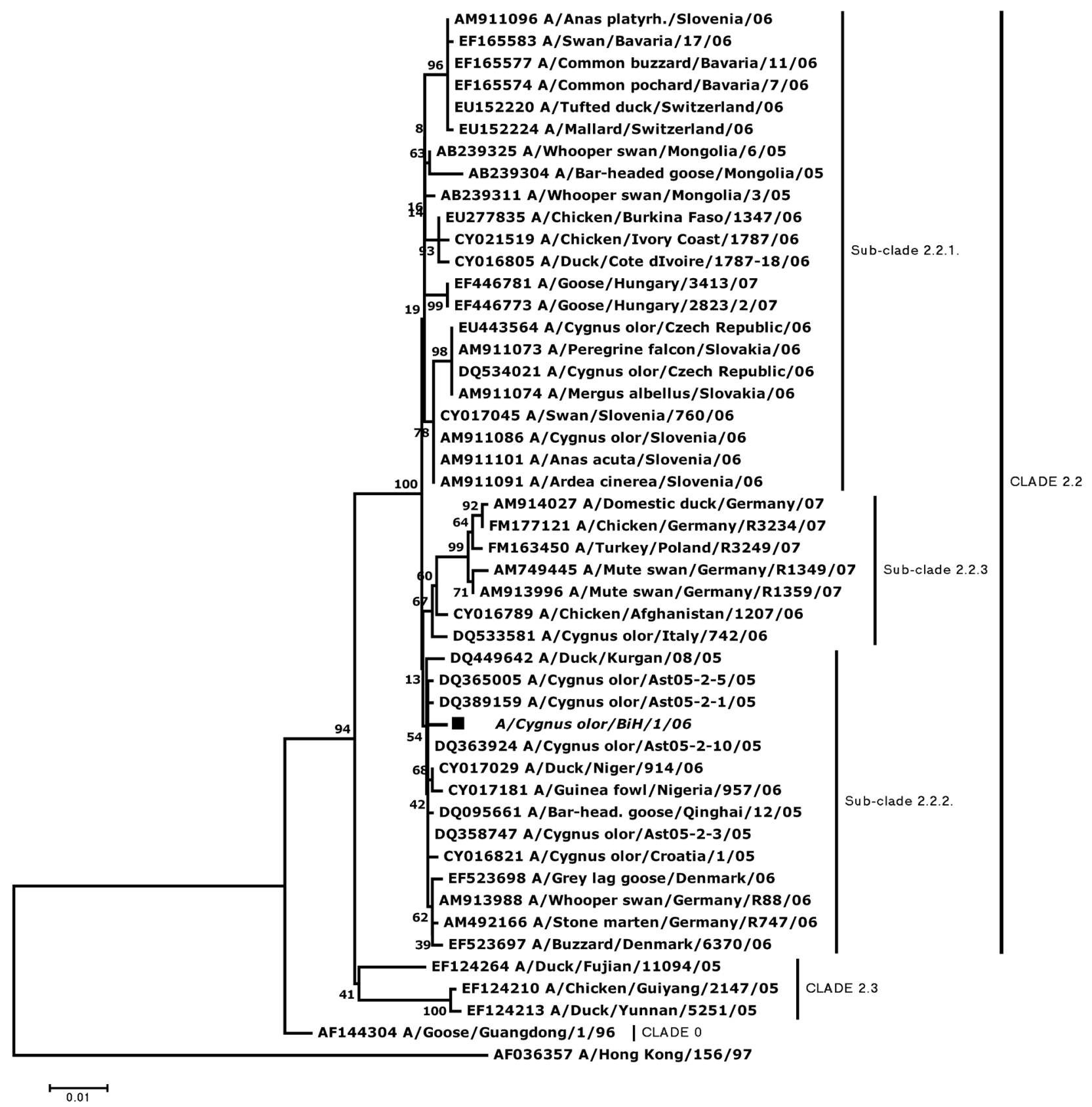

Figure 2. Evolutionary relationship of NA gene of BIH HPAIV $\mathrm{H}_{5} \mathrm{~N}_{1}$

Figure 2 shows the evolutionary relationship of NA gene of BIH HPAIV $\mathrm{H}_{5} \mathrm{~N}_{1}$ compared to the fifty most homologous sequences obtained from GenBank. The tree comprising the whole protein coding region (nt $36-1385$ ) was generated by neighbor-joining analysis with Tamura-Nei $\gamma$ - model, using MEGA 4.o. Numbers below key nodes indicate percentage bootstrap values of 2000 replicates. The lengths of the horizontal lines are proportional to the number of nucleotide differences per site. Scale bar indicates number of nucleotide substitutions per site. Genetic clades are designated according to WHO/FAO/OIE $\mathrm{H}_{5} \mathrm{~N}_{1}$ Evolution Working Group [24]. Tree is midpoint rooted for means of clarity. The BIH virus is highlighted by italic bold letters. 


\section{CONCLUSION}

In conclusion, HPAIV $\mathrm{H}_{5} \mathrm{~N}_{1}$ infection in wild birds was observed for the first time in Bosnia and Herzegovina in February 2006.

Sequence comparison of all gene segments with relevant sequences in GenBank revealed that the $\mathrm{BiH}$ isolates and the ones from Astrakhan region in southern Russia group together phylogenetically, forming a monophyletic cluster and indicating that these isolates have evolved from the same origin. Based on this it is highly likely that the introduction of HPAIV $\mathrm{H}_{5} \mathrm{~N}_{1}$ into BIH occurred due to wild birds' unusual migration routes during harsh winter conditions 2005 - 2006 in southern Russia and Ukraine.

Three residues $(\mathrm{M} 2-28 \mathrm{~V}$ and $78 \mathrm{~K}, \mathrm{NP}-33 \mathrm{I})$, typical of human influenza viruses, were found, indicating a certain degree of intercurrent evolutionary adaptive changes in $\mathrm{BiH}$ isolates. Sequence derived phenotype markers of NA protein (E99, V129, D131, R136, H255 and $\mathrm{Y}_{256}$ ) as well as of M2 protein (26L, 27V, 30A, S31 and $\mathrm{G}_{34}$ ) showed that the isolates have an oseltamivir and amantadine sensitive genotype, important for treatment in case of human infections with this strain.

\section{SAŽETAK}

Ciljevi: Identifikacija genetske strukture i molekularno-bioloških karakteristika $\mathrm{BiH}$ izolata virusa VPIP $\mathrm{H}_{5} \mathrm{~N}_{1}$ te procjena njihova patogeniteta, filogenetskog porijekla i vrsne specifičnosti.

Materijal i metode: Za izolaciju virusa korištena su SPF embrionirana kokošija jaja. Za PCR amplifikaciju korištena je virusna RNK ekstrahovana pomoću QIAamp viral RNK kita prema protokolu proizvođača (QIAGEN ${ }^{\oplus}$ ). Za svih osam viralnih RNK segmentata pojedinačno, korištenjem odgovarajućih setova genspecifičnih prajmera (sekvence prajmera dostupne na zahtjev), izvršena je sinteza cDNK te potom PCR amplifikacija. Sekvenciranje je izvedeno pomoću Prism Big Dye Terminator v1.1 cycle sequencing kita (Applied Biosystems) na ABI PRISM 3130 platformi (Applied Biosystems). Softverski paket Bioedit (v. 7.o.9.0), temeljen na Custal W 1.4 algoritmu korišten je za analizu dobijenih nukleotidnih sekvenci. Za procjenu filogenetskih odnosa i izračun bootstrap vrijednosti korišten je Tamura-Nei $\gamma$ model NJ modula (Neighbour-Joining tree inference analysis) MEGA 4.0 softvera,

Rezultati: Kompletne nukleotidne sekvence A/ Cygnus olor/BIH/1/20o6 $\left(\mathrm{H}_{5} \mathrm{~N}_{1}\right)$ soja deponirane su u genskoj bazi GenBank pod pristupnim brojevima FN1860o8 do FN186014 i FM20943. Budući da su patogenost i vrsna specifičnost poligene osobine, in silico određene su proteinske strukture soja, naročito njegovih površinskih glikoproteina, HA i NA. Utvrđeno RBS tipično je za ptičije influenca viruse, sa Gln i Gly na pozicijama 238 i $240 \mathrm{HA}$ gena ( $\mathrm{H}_{5}$ označavanje) koje odgovaraju pozicijama 226 i $228 \mathrm{H}_{3}$ označavanja uz sedam potencijalnih glikolizirajućih područja, ali i sa povećanom sposobnošću vezivanja na alfa26 sialoglikane uzrokovanom supstitucijama, kako slijedi, $110 \mathrm{~N}, 171 \mathrm{~N}, 171 \mathrm{~N}, 172 \mathrm{~A}, 205 \mathrm{R}$ i $251 \mathrm{P}$. Višebazni aminokisleinski slijed PQGERRRKKR/GLF, marker sojeva visokog patogeniteta, utvrđen je na mjestu cijepanja HA BiH soja. Prema strukturi NA, ovaj soj pripada $\mathrm{Z}$ genotipu za kojega je karakteristično i brisanje pet aminokiselinskih rezidua NSı proteina (pozicije 8o-84) zahvaljujući čemu se ovi virusi, vrlo uspješno multipliciraju čak i u prisustvu visokih nivoa citokina. Od ukupno 43 aminokiselinske residue, situiranih na M1, M2, NP, PA, PB2 i HA, bitnih za utvrđivanje vrsne specifičnosti, njih 40 su tipične za ptičije influenca viruse. Filogenetskom analizom HA gena utvrđeno je da $\mathrm{BiH}$ izolati pripadaju genetskoj skupini 2.2, dok prisustvo asparaginske kiseline (Asp) na poziciji $403 \mathrm{HA}$ svrstava $\mathrm{BiH}$ izolate u podskupinu 2.2.2.

Zaključak: BiH izolati pripadaju skupini VPIP virusa dok su HA i NA sekvence najsličnije soju A/Cygnus olor/ Astrakhan/Asto5-2-10/2005 $\left(\mathrm{H}_{5} \mathrm{~N}_{1}\right)$. Tri rezidue (M228V i 78K, NP-33I), tipične za viruse humane influence, utvrđene u $\mathrm{BiH}$ izolatima, ukazuju na određeni stepen međuvrsnih evolutivnih adaptivnih promjena. Fenotipski markeri (E99, V129, D131, R136, H255 i Y256) NA proteina ukazuju da $\mathrm{BiH}$ izolati pripadaju oseltamivir-osjetljivom genotipu. Komparacija sekvenci HA i NA segmenata sa odgovarajućim sekvencama GenBank genetske baze je pokazala da se $\mathrm{BiH}$ izolati filogenetski grupiraju sa onima iz južne Rusije (područje Astrahana), formirajući monofiletske klastere, što ukazuje na njihovo zajedničko porijeklo.

Ključne riječi: $\mathrm{H}_{5} \mathrm{~N}_{1}$, HPAI, pathogenitet, filogenetsko porijeko, vrsna spcifičnost

\section{REFERENCES}

1. Imai M, Watanabe T, Hatta M, Das SC, Ozawa $\mathrm{M}$, Shinya $\mathrm{K}$ et al. Experimental adaptation of an influenza $\mathrm{H}_{5} \mathrm{HA}$ confers respiratory droplet transmission to a reassortant $\mathrm{H}_{5} \mathrm{HA} /$ $\mathrm{H}_{1} \mathrm{~N}_{1}$ virus in ferrets. Nature 2012; 486: 420428.

2. Herfst S, Schrauwen EJA, Linster M, Chutinimitkul, S, de Wit E, Munster VJ et. al. Airborne transmission of influenza $\mathrm{A} / \mathrm{H}_{5} \mathrm{~N}_{1}$ virus between ferrets. Science 2012; 336: 15341541.

3. Goletić T, Gagić A, Rešidbegović E, Kustura A, Kavazović A, Savić V et al. Highly pathogenic avian influenza virus subtype $\mathrm{H}_{5} \mathrm{~N}_{1}$ in mute swans (Cygnus olor) in Central Bosnia. Avian Dis 2010; 54(1 Suppl): 496-501.

4. Office International des Epizooties (OIE). Avian influenza (infection with avian influenza viruses). In: OIE Terrestrial Manual 2018, Chapter 3.3.4.

5. European Economic Community (EEC). Commission decision of 4 August 2006 approving a Diagnostic Manual for Avian Influenza as provided for in Council Directive 2005/94/EC (notified under document number C (2006) 3477) (Text with EEA 
relevance) (2006/437/EC). Official Journal of the European Union L 237: 1-27. 2006.

6. Hoffmann E, Stech J, Guan Y, Webster R, G, Perez DR. Universal primer set for the fulllength amplification of all influenza A viruses. Arch Virol 2001; 146(12): 2275-2289.

7. Hall TA. BioEdit: a user-friendly biological sequence alignment editor and analysis program for Windows 95/98/NT. Nucleic Acids Symposium Series (Oxford University Press, Oxford) 41:95-98.

8. Tamura K, Dudley J, Nei M, Kumar S. MEGA4: Molecular Evolutionary Genetics Analysis (MEGA) software version 4.o. Mol Biol Evol 2007; 24(8): 1596-1599.

9. Gupta R, Jung E, Brunak S. Prediction of $\mathrm{N}$-glycosylation sites in human proteins. 2004. http://www.cbs.dtu.dk/services/NetNGlyc/.

10. Lu G, Rowley T, Garten R, Donis RO. FluGenome: a web tool for genotyping influenza A virus. Nucleic Acids Res. 2007; 35(Web Server issue): W275-W279.

11. Horimoto T, Kawaoka Y. Reverse genetics provides direct evidence for a correlation of hemagglutinin cleavability and virulence of an avian influenza A virus. J Virol. 1994; 68(5):3120-

12. Schrauwen EJ, Herfst S, Leijten LM, van Run P, Bestebroer TM, Linster M et al. The multibasic cleavage site in $\mathrm{H}_{5} \mathrm{~N}_{1}$ virus is critical for systemic spread along the olfactory and hematogenous routes in ferrets. J Virol 2012; 86(7): 3975-3984.

13. Kim P, Jang YH, Kwon SB, Lee CM, Han G, Seong BL. Glycosylation of Hemagglutinin and Neuraminidase of Influenza A Virus as Signature for Ecological Spillover and Adaptation among Influenza Reservoirs. Viruses 2018; 10(4). pii: E183.

14. Matrosovich M, Zhou N, Kawaoka Y, Webster R. The surface glycoproteins of $\mathrm{H}_{5}$ influenza viruses isolated from humans, chickens, and wild aquatic birds have distinguishable properties. J Virol 1999; 73(2): 1146-1155.

15. Hatta M, Gao P., Halfmann P, Kawaoka Y. Molecular basis for high virulence of Hong Kong $\mathrm{H}_{5} \mathrm{~N}_{1}$ influenza A viruses. Science 2001; 293: 1840-1842

16. Vines A, Wells K, Matrosovich M, Castrucci MR, Ito T, Kawaoka Y. The Role of Influenza A Virus Hemagglutinin Residues 226 and 228 in Receptor Specificity and Host Range Restriction. J Virol 1998; 72(9): 7626-7631.

17. Zhang Y, Aevermann BD, Anderson TK, Burke DF, Dauphin G, Gu Z et al. Influenza Research Database: an integrated bioinformatics resource for influenza research. Nucleic Acids Res 2017; 45(D1): D466-D474.

18. Ha Y, Stevens DJ, Skehel JJ, Wiley DC. X-ray structures of $\mathrm{H}_{5}$ avian and $\mathrm{H}_{9}$ swine influenza virus hemagglutinins bound to avian and human receptor analogs. Proc Natl Acad Sci USA 2001; 98(20): 11181-11186.

19. Hulse DJ, Webster RG, Russell RJ, Perez DR. Molecular Determinants within the Surface Proteins Involved in the Pathogenicity of $\mathrm{H}_{5} \mathrm{~N}_{1}$ Influenza Viruses in Chickens. J Virol 2004; 78(18): 9954-9964.
20. Li WX, Li H, Lu R, Li F, Dus M, Atkinson P et al. Interferon antagonist proteins of influenza and vaccinia viruses are suppressors of RNA silencing. Proc Natl Acad Sci USA 2004; 101(5): 1350-1355.

21. Seo SH, Hoffmann E, Webster RG. The NS1 gene of $\mathrm{H}_{5} \mathrm{~N}_{1}$ influenza viruses circumvents the host anti-viral cytokine responses. Virus Res 2004; 103(1-2): 107-113.

22. Russell RJ, Haire LF, Stevens DJ, Collins PJ, Lin YP, Blackburn GM et al. The structure of $\mathrm{H}_{5} \mathrm{~N}_{1}$ avian influenza neuraminidase suggests new opportunities for drug design. Nature 2006; 443(7107): 45-49.

23. Pabbaraju K, Ho KC, Wong S, Shokoples S, Pang XL, Fonseca K, Fox JD. Adamantane resistance in circulating human influenza A viruses from Alberta, Canada (1970-2007). Antiviral Res 2008; 79(2): 81-86.

24. WHO/FAO/OIE $\mathrm{H}_{5} \mathrm{~N}_{1}$ Evolution Working Group. Toward a unified nomenclature system for highly pathogenic avian influenza virus $\left(\mathrm{H}_{5} \mathrm{~N}_{1}\right)$. Emerg Infect Dis 2008; 14(7): e1.
Scan this QR code with your mobile device for instant access to the current Issue of Acta Medica Saliniana

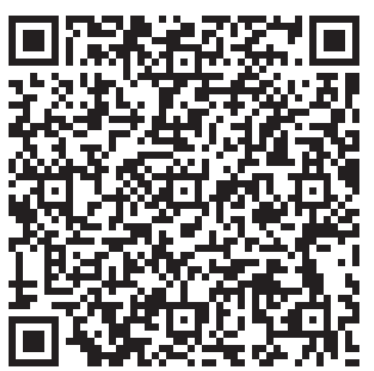

